\title{
The Role of Religions on Politics, Economics, and Social Class in the Society: A Phenomenological Study
}

\author{
Twin Hosea W. Kristyanto ${ }^{1 *}$, Rikardo P. Sianipar ${ }^{2}$, Andreas E. Nugroho ${ }^{3}$, and Twin \\ Twin Yoshua R. Destyanto ${ }^{4}$
}

\author{
1,2,3,4 Prodi Magister Teologi, STTB The Way, Jakarta, Indonesia
}

*Corresponding author.Email: twin.hosea@sci.ui.ac.id

\begin{abstract}
Living in society could not be separated from religion. The fact that religions can create the culture of a nation shows that religions possess an influence that cannot be ignored. Besides, there are also social conflicts that occurred due to religious matters. Those religious conflicts have raised scepticism for the possibility of building a peaceful interreligious dialogue. Therefore, this paper aims to explain the role of religions on politics, economics, and social class in society, as a bridge for inter-religious dialogue. This research used a literature study and phenomenological approach as the methods. The results show that there are similar views among the religions to see their role in politics, economics, and social class. Those common grounds could be used to build the bridge for a peaceful inter-religious dialogue. However, the existence of radical fundamentalists should be well controlled to support the bridge construction. Thus, the conclusion is that it is possible to have an inter-religious dialogue using their role on political, economics, and social class as the topics to be discussed, unless the religious fundamentalist's activity is not well controlled.
\end{abstract}

Keywords: religion, society, economics, politics, social class.

\section{INTRODUCTION}

Talking about living in society, especially in Indonesia, it could not be separated from the belief system called religion. In a long of the history of people, religion has been an important part of the social system [1, p. 80], [2, p. 24], [3, pp. 163-164]. The fact that religions can create and maintain the culture of a particular nation shows that religion possesses an influence that cannot be ignored when we talk about human civilization [4, pp. 795-797].

One of the historical notes regarding the roles of religion in creating the culture of a nation can be seen in the Jewish culture. Moses wrote a set of rules in the Torah to manage the life of Jacob's offspring. It started from how the manner for the clothes is, how to deal with social conflicts (e.g., Exo. 21:12-36), to how the custom to defecate is regulated in it (Deu. 23:12) [5, pp. 21, 27], [6]. Another example is reflected by Minang Culture, in determining their identity as Minang. For them, having Minang blood does not enough for someone could be called Minangese. He/she should fulfil the first qualification that is also be a Moslem [7]. For Minangese, turning away from the Islamic faith is the same as giving up their identity as Minang people. This loyalty to Islam has succeeded in maintaining the homogeneity of their society from the aspect of belief [8, pp. 66-68].

On the other hand, there are also social conflicts that arise with religious backgrounds. An example is the use of religion as a political vehicle by the elite during the campaign period. The case of politicization of religion, during the past 2017 DKI Jakarta governor election period, set a bad precedent for the abuse of religion to achieve the political desires of a particular group of people. The practice of identity politics, in this case, religious sentiment, has succeeded in dividing society into several opposing camps. Not only those with different religions but also those who come from the same religion, are divided into several extreme groups. Call it a boycott call or a ban on funeral prayers for supporters of one of the governor candidates at that time [9, pp. 14-15].

Another example is the problem of terrorism did by certain radical groups which is still become some homework for the government today. The act of terrorism in the name of religion has succeeded in dividing society into various views. There are even those who think that 
religion is a good ladder to get to terrorism $[10$, p. 76$]$, [11, p. 593], [12, p. 632].

Those roles of religions, either positively or negatively, have raised the question of whether it is possible or not to build a bridge to connect people, from various religious backgrounds, to sit together peacefully. Thus, this paper aims to explain the role of religions on political, economic, and social class, in society, as a bridge for inter-religious dialogue.

\section{METHOD}

In compiling this article, a qualitative method was used, i.e., a method that uses an inductive approach to interpret descriptive data, and has a purpose to find meaning/theory or to understand a phenomenon $[13, \mathrm{p}$. 33]. There were two qualitative approaches used in this research. The first one is the systematic literature study method, which is an approach by looking for references that are appropriate to the case or topic being studied. These references can be obtained from journals, book chapters, and other articles that provide an overview of theories from the past or the present, which are organized into new knowledge, in this case, the study of religion and society [14, pp. 92-93].

The second qualitative method that was used in this research is the phenomenology approach. It is an art of describing what a person sees, what he/she feels and knows in his/her immediate awareness and experience [15, pp. 273-274]. This method is an approach that tries to "return to the object under study itself". It means that in researching a phenomenon, a researcher should refrain from assessing a study; until the researcher looks directly at the object, that is the phenomenon or senses the testimony of others who have known or experienced the phenomenon [16, pp. 350-351]. In this research, the phenomenological analysis was carried out through indepth interviews with 3 interviewees consisting of a Christian religious leader in Bali (T), a former agnostic (L) who lives in Jakarta, and an Islamic religious leader (F) domiciled in Special Region of Yogyakarta.

\section{FINDINGS AND DISCUSSION}

\subsection{Religions and Society}

According to Marzali, religion is everything related to beliefs and rituals that are owned collectively by a group of people. Religion is also related to a human's transcendent experience with a Person who is above or beyond him/herself [10, p. 59]. Meanwhile, Sodikin defines religion as a complete set of rules given by God to His creation, in this case, humans, in order to obtain the goodness of life in this world and the hereafter [11, p. $1]$.
In religious life, the term religious fundamentalist is known, which has various meanings according to the context. For Western society, fundamentalists are always associated with the connotation of violence through the label that the West attaches to them. The label, among others, refers to fundamentalists as militant, radical, terrorist, modernist, liberal and secularist groups. On the other hand, academics call the fundamentalist movement more as opposed to the adherents of modernism and secularism [12, p. 141].

Meanwhile, society is a group of people who are strongly bound by a system, culture, and the same law, and this group of people is oriented to live collectively $[13, \mathrm{p} .1]$. The bound in society is built by a system within the community itself that connects everyone in it [14]. The characteristics of a society are formed and influenced by the combined nature of each member of society itself. Thus, social interactions between individuals will determine what the personality of the community will be like [15, pp. 175-177].

This social interaction will form a constellation called social structure, as the forerunner to the characteristics of the community. This social structure becomes the genetic code, determining the uniqueness, of a society. In sociocultural reality, the social structure will help community members to behave and understand the values held by the community. If the spirit of the social structure, which is the interaction, disappears, then the existence of society also vanishes [16]. Therefore, dynamic social interactions will ensure the sustainability of a society.

In society at least there are two kinds of interaction between people within it, they are political and economic interaction [16]. Political interaction is built by the need for an authoritative effort to solve social conflict within society [17]. While economical one is born because of production, distribution, and consumption activity in the society due to interdependent relationship between the people within it [18]. The political and economic interest in the society could result in distinction among the member of a society called social classes, either horizontally or vertically $[19$, p. 229], [20, p. 19]. Therefore, in further discussion, the role of religions in politics, economics, and social class in the body of society is addressed.

\subsection{Religions' Role on Politics}

Based on T's view, the trend in Indonesia is that religion determines the political identity of community members. That is, the religious identity and ideology determine the political decisions of society in Indonesia. The religion adopted by a community leader is an important factor in the submission of members of the community he leads. In short, according to L, religion also affects the government system of a country, especially countries which are based on religion such as 
Pakistan or Afghanistan. For example, in a patriarchal culture that is so Islamic. F also agrees with this by arguing that religion determines the organizational structure and state life of a society.

In line with those insights, it could be understood that the relationship between religion and politics is like the relationship between insects and flowers, i.e., a reciprocal relationship. It is due to the conflict of interest between the two entities. Religion plays a role in shaping the system of values and norms to build the framework of the state and to discipline society. On the other hand, community institutions, such as the government, often use religion to bind community members to obey the rules made by these institutions [21, p. 134].

\subsection{Religions' Role on Economics}

$\mathrm{T}$ focuses more on the role of religions in affecting the price fluctuations of basic commodities in Indonesia when religious holidays are coming. In addition, specifically in Bali, religious celebrations also determine tourism economic activity in the region. Economic activity in Bali will practically stop during Nyepi or Galungan celebrations. In line with $\mathrm{T}, \mathrm{L}$ agrees that religion plays a role in economic activities. $\mathrm{L}$ highlighted the soaring prices of necessities as the religious holidays approach.

$\mathrm{L}$ also views that Western economic principles, which are liberal and capitalist, are also influenced by Christian values, for example, the influence of the Apostle Paul's words that people who do not work are prohibited from eating. Meanwhile, F stated that today, the role of religion is getting bigger in determining the economic system of Indonesian society. It can be seen from the merging of Islamic State-owned banks into one which confirms the solemnity of the government in the field of Islamic economics. It implies that Islamic economics, in Indonesia, is not only about banking transactions but also about capital market activities.

\subsection{Religions' Role on Social Class}

The influence of religions in the formation of social class is also seen, although not so explicitly, by $\mathrm{T}$ in determining someone to become a public official in an area. Religions do determine someone' superiority in politically hierarchy or class. For example, there was an identity consideration in the recent process of replacing the Regional Police Leader in Bali, who has a nonBalinese Christian background. On the other hand, L does not see any class system built by religion, including religion that adheres to the caste system. L explained that even religions that recognize caste, today, do not divide the class in society, especially economic class. In fact, specifically Christianity, its teachings help in the abolition of social class, for example in terms of class or economic strata. Meanwhile, FAT firmly and briefly states that the religion he adheres to, i.e., Islam, does not recognize the existence of caste in society.

\subsection{The Common Ground and Its Obstacles}

From the discussion above, it could be stated that there are many similar views of each religion toward the role of them on politics, economics, and social class. The awareness of religions' impact on the condition of politics could be the basis to prevent negative impacts of imbalance doctrine that can affect the political stability. In the economical aspect, each religion's view agrees that they could control the economic system within society. Respectful and emphatical religious views could help build a stable economic system and condition in a particular society. Most, if not all, religious views nowadays also support the reduction even elimination of human inequality called social classes. They commonly view that every human is equal before God so that the equality issues in society should be prioritized.

Besides those common grounds that could be the bridge for inter-religious dialogue, there are also obstacles that could prevent the bridge to be built safely. One of them is the existence of religious fundamentalists. They say that their religious doctrine is the rightest and the rest is not. This builds a high wall instead of bridging for inter-religious dialogue. This radical view already results in several intolerance actions in many areas in Indonesia. If this trend is not well managed, it will become a time bomb for the unity of the society that builds from members that have various religious backgrounds.

\section{CONCLUSION}

Based on the literature study and phenomenological analysis, it could be concluded that there are many similar views between religions in looking at their role in politics, economics, and social class in society. These same views and considerations could be used for the bridge that can connect various religions to sit together thinking about the sustainability of the society. It is possible to do so unless the religious fundamentalist' activity is not well managed or regulated. Therefore, the society, as a teamwork between the leader and people they lead, should ensure that they could prevent and control the existence of a radical community called a religious fundamentalist. For further research, it could be discussed about the way that can be used to prevent this religious fundamentalist' growth in the society.

\section{AUTHORS' CONTRIBUTIONS}

Twin Kristyanto (TK) and Rikardo Sianipar (RS) developed the theory and determined the framework. TK and Twin Destyanto (TD) set the interviewees for the phenomenological interview, under the supervision of RS and Andreas Nugroho (AN), and interviewed them. 
All authors gave their insights and input to compile and synthesize all data in answering the aim of the research. TK and TD prepared the manuscripts while RS and AN supervised and gave the advice to do it.

\section{ACKNOWLEDGMENTS}

Thanks to LPPM STTB The Way for funding the research and the submission related fees.

\section{REFERENCES}

[1] R. Rahman, S. Sos, and M. Si, "Peran Agama dalam Masyarakat Marginal," Oct. 2019. Accessed: May 15, 2021. [Online]. Available: http://103.55.216.56/index.php/Sosioreligius/arti cle/view/10661.

[2] A. Amran, "Peranan agama dalam perubahan sosial masyarakat," HIKMAH J. Ilmu Dakwah Dan Komun. Islam, vol. 2, no. 1, pp. 23-39, 2015.

[3] R. Mubit, "Peran Agama dalam Multikulturalisme Masyarakat Indonesia," Epistemé J. Pengemb. Ilmu Keislam., vol. 11, no. 1, pp. 163-184, 2016.

[4] P. Lakonawa, "Agama dan pembentukan cara pandang serta perilaku hidup masyarakat," Humaniora, vol. 4, no. 2, pp. 790-799, 2013.

[5] B. M. Kelly, "Functions of dress according to the Torah," 1989.

[6] L. A. Indonesia, "Alkitab Terjemahan Baru," Jakarta LAI, 1997.

[7] L. Asriani, "Masalah-Masalah Sosial dalam Novel dari Subuh Hingga Malam: Perjalanan Seorang Putra Minang Mencari Jalan Kebenaran Karya Abdul Wadud Karim Amrullah," $J$. Bastra (Bahasa dan Sastra), vol. 1, no. 01, 2016.

[8] N. Anggraini, "Pergeseran Nilai Budaya Minangkabau Dalam Novel Dari Surau Ke Gereja Karya Helmidjas Hendra Dan Novel Persiden Karya Wisran Hadi (Tinjauan Sastra Banding)," J. Din. UMT, vol. 1, no. 1, pp. 6370, 2015.

[9] D. Lestari, "Pilkada DKI Jakarta 2017: Dinamika Politik Identitas di Indonesia," JUPE J. Pendidik. Mandala, vol. 4, no. 4, pp. 12-16, 2019.

[10] A. Marzali, “Agama dan Kebudayaan,” Umbara, vol. 1, no. 1, Mar. 2017, doi: 10.24198/umbara.v1i1.9604.

[11] R. A. Sodikin, "KONSEP AGAMA DAN ISLAM," ALQALAM, vol. 20, no. 97, p. 1, Jun. 2003, doi: 10.32678/alqalam.v20i97.643.
[12] F. Fihris, "The Effect of Academic Background and Religious Orientation to Religious Fundamentalism among University Students," Nadwa, vol. 14, no. 1, pp. 129-154, Sep. 2020, doi: 10.21580/nw.2020.14.1.6118.

[13] I. S. Wekke, H. Asrori, R. W. Eko s, S. Salvia, Y. Wulandari, and F. Firdaus, "PASAR, MASJID, DAN MADRASAH: PENDIDIKAN ISLAM DI MINORITAS MUSLIM," Qalam $J$. Ilmu Kependidikan, vol. 7, no. 1, p. 1, Jan. 2019, doi: 10.33506/jq.v7i1.352.

[14] B. Tejokusumo, "Dinamika masyarakat sebagai sumber belajar ilmu pengetahuan sosial," Geo Edukasi, vol. 3, no. 1, 2014.

[15] N. Effendi, "Pemahaman dan Pembentukan Karakter Masyarakat: Realitas dan Pandangan Antropologi," Oct. 2016. Accessed: Jun. 18, 2021. [Online]. Available: http://nasional.sindonews.com/.

[16] B. Waluya, Sosiologi: Menyelami fenomena sosial di masyarakat. PT Grafindo Media Pratama, 2007.

[17] M. Rush, Politics \& Society. Routledge, 2014.

[18] P. Chalid, "Sosiologi Ekonomi," Jakarta: Center for Social Economic Studies (CSES) Press, 2009. https://repository.uinjkt.ac.id/dspace/handle/123 456789/33469 (accessed May 19, 2021).

[19] J. D. McLeod, "Social stratification and inequality," in Handbook of the sociology of mental health, Springer, 2013, pp. 229-253.

[20] B. Maunah, "Stratifikasi Sosial dan Perjuangan Kelas dalam Perspektif Sosiologi Pendidikan," Ta'allum J. Pendidik. Islam, vol. 3, no. 1, pp. 19-38, Jun. 2015, doi: 10.21274/taalum.2015.3.1.19-38.

[21] W. Raharjo Jati, "Agama dan Politik : AGAMA DAN POLITIK: Teologi Pembebasan sebagai Arena Profetisasi Agama," LP2M - Universitas Islam Negeri (UIN) Walisongo, Jun. 2014. doi: 10.21580/WS.22.1.262. 